\title{
Predictive clinical parameters for the response of nivolumab in pretreated advanced non-small-cell lung cancer
}

\author{
Yuko Oya $^{1}$, Tatsuya Yoshida ${ }^{1}$, Hiroaki Kuroda ${ }^{2}$, Masashi Mikubo $^{3}$, Chiaki Kondo ${ }^{1}$, \\ Junichi Shimizu' ${ }^{1}$, Yoshitsugu Horio ${ }^{1}$, Yukinori Sakao², Toyoaki Hida' ${ }^{1}$ and Yasushi \\ Yatabe $^{3}$ \\ ${ }^{1}$ Department of Thoracic Oncology, Aichi Cancer Center Hospital, Nagoya, Japan \\ 2 Department of Thoracic Surgery, Aichi Cancer Center Hospital, Nagoya, Japan \\ ${ }^{3}$ Department of Pathology and Molecular Diagnostics, Aichi Cancer Center Hospital, Nagoya, Japan
}

Correspondence to: Tatsuya Yoshida, email: t.yoshida@aichi-cc.jp

Keywords: nivolumab, non-small cell lung cancer, programmed cell death-1(PD-1), programmed cell death-ligand 1 (PD-L1)

Received: June 27, 2017 Accepted: September 21, $2017 \quad$ Published: October 07, 2017

Copyright: Oya et al. This is an open-access article distributed under the terms of the Creative Commons Attribution License 3.0 (CC BY 3.0), which permits unrestricted use, distribution, and reproduction in any medium, provided the original author and source are credited.

\section{ABSTRACT}

Background: Nivolumab offers a superior survival benefit over docetaxel in patients with advanced, previously treated non-small-cell lung cancer (NSCLC). An association between programmed cell death ligand-1 (PD-L1) expression and the efficacy of nivolumab has been reported in many studies. However, the association between the clinical parameters and efficacy of nivolumab remains unclear in advanced NSCLC patients.

Results: Among 124 patients, 108 (88\%) were performance status (PS) 0 to 1. PD-L1 expression was assessed in 89 patients, with $51(57 \%)$ patients having PD-L1 positive expression. In all patients, the objective response rate (ORR) in patients with elevated CRP levels ( $\geq 1 \mathrm{mg} / \mathrm{dl}$ ) was significantly worse than those without elevated CRP levels ( $<1 \mathrm{mg} / \mathrm{dl}$ ) (8.3 vs $23.4 \%, p=0.0180)$. The PS $(\geq 2)$, smoking index (< 400), CRP levels ( $\geq 1 \mathrm{mg} / \mathrm{dl}$ ) and LDH ( $\geq 245 \mathrm{IU} / \mathrm{L}$ ) were significantly associated with a shorter PFS and OS in patients treated with nivolumab. Multivariate analyses showed that the PS ( $\geq 2)$, smoking index $(<400)$, CRP levels $(\geq 1 \mathrm{mg} / \mathrm{dI})$ and LDH ( $\geq 245 \mathrm{IU} / \mathrm{L}$ ) and PD-L1 expression were significant factors associated with a longer PFS of nivolumab.

Materials and Methods: We retrospectively analyzed 124 patients who received nivolumab as a subsequent treatment. The patient characteristics, laboratory data at baseline (C-reactive protein [CRP] and lactate dehydrogenase [LDH]), PD-L1 expression, nivolumab response, progression-free survival (PFS), and overall survival (OS) were evaluated.

Conclusions: Clinical parameters, such as PS, serum CRP, serum LDH, and smoking status, were significantly associated with the response duration and survival in patients treated with nivolumab.

\section{INTRODUCTION}

Programmed cell death (PD)-1 immune checkpoint inhibitors have emerged as promising treatment options for multiple cancer types. These inhibitors bind with high affinity to the PD-1 receptors expressed on T cells and disrupt the negative signaling induced by PD-ligand 1 (PD-L1) and PD-L2 to restore T-cell effector function
[1]. PD-1 inhibitors, nivolumab and pembrolizumab, were recently approved for treatment of advanced nonsmall-cell lung cancer (NSCLC). Nivolumab monotherapy showed a statistically superior survival benefit over docetaxel, which was standard therapy as a second line therapy in patients with advanced, previously treated NSCLC in two phase 3 studies [2-5]. The objective response rate (ORR) of nivolumab was approximately 
$15 \%$, with the majority of responses persisting after treatment discontinuation in patients who stopped therapy for reasons other than disease progression $[6,7]$.

PD-L1 expression on tumor cells may be a possible predictive marker of a clinical response to anti-PD-1/PD-L1 antibodies. Indeed, the association of PD-L1 expression and the efficacy of them have been investigated in many studies [2, 3, 8, 9]. In phase III trials of nivolumab for previously treated non-squamous (SQ) NSCLC patients, PD-L1 expression was associated with the efficacy of nivolumab. In addition, first-line pembrolizumab has demonstrated significantly longer survival times compared to chemotherapy for PD-L1 expression strong positive NSCLC [10]. However, many patients with PD-L1 positive tumors do not respond to anti PD-1/PD-L1 antibodies, and some responses occur in patients with PD-L1 negative tumors [9]. Therefore, PD-L1 expression is not enough to predict the outcome to anti-PD-1/PD-L1 therapy. Recently, some biomarkers of PD-1 inhibitors and PD-L1 inhibitors efficacy, including high tumor mutational load $[11,12]$, neoantigen $[11,13]$, increased CD8 positive tumor-infiltrating lymphocytes in the tumor microenvironments [14], increased PD-L1 expression on immune cells $[15,16]$, and the presence of epidermal growth factor receptor $(E G F R)$ mutation [17], have been reported. Unfortunately, these biomarkers are not entirely reliable and impractical. Reliable predictive markers that can be used to select patients with a higher likelihood of benefit from immune checkpoint inhibitors are needed. Additionally, some reports have suggested an association between clinical parameters, such as lactate dehydrogenase $(\mathrm{LDH})$ and C-reactive protein (CRP), and the efficacy of immune checkpoint inhibitor in metastatic melanoma patients [18-21]. In contrast, there are few reports of the association between clinical parameters and the efficacy of anti-PD-1/PD-L1 therapy in advanced NSCLC patients. In addition, patients with poor performance status were not included in the antiPD-1/PD-L1 antibodies trials. Therefore, we investigated various factors, including PD-L1 expression, on tumor, laboratory findings, and PS to identify predictive markers of nivolumab therapy in patients with NSCLC in this study.

\section{RESULTS}

\section{Patients and treatment}

The median follow-up was 6.0 months (range: 0.1 to 22.5 months). Patient characteristics are summarized in Table 1. The median age of the patients was 66 (range, 37$79)$ years. Eighty-one patients $(65 \%)$ had adenocarcinoma (Ad), and seventy-seven (62\%) patients were heavy smokers (smoking index $[\mathrm{SI}] \geq 400$ ). One hundred nine $(88 \%)$ patients were ECOG PS score 0 to 1 , with 15 $(12 \%)$ patients at PS 2 to 3 . All patients received cytotoxic chemotherapy previously, and 58 (47\%) patients received nivolumab treatment as second line treatment (98\% patients received platinum doublet chemotherapy). The median number of doses of nivolumab was five (range, 1 to 25 ). At the time of the database lock, $31 \%$ of the patients were continuing nivolumab treatment. Twenty-two patients (18\%) harbored EGFR mutation, 14 (11\%) had KRAS mutations, 5 (4\%) had HER2 mutation, 2 (2\%) patients had BRAF V600E mutation, and no patients had $A L K$ rearrangement. The median serum $\mathrm{LDH}$ and $\mathrm{CR} P$ values were $224 \mathrm{IU} / \mathrm{L}$ and $0.87 \mathrm{mg} / \mathrm{dl}$. The $\mathrm{LDH}(\geq 245 \mathrm{IU} / \mathrm{L})$ and CRP $(\geq 1.0 \mathrm{mg} / \mathrm{dl})$ were elevated in $51(41 \%)$ and 60 $(48 \%)$ patients, respectively. For efficacy measurements, the ORR and median PFS in all patients were $16.1 \%$ (95\% confidence interval [CI]: 10.7-23.6) and $2.8(95 \%$ CI: $2.1-4.0)$ months (Figure 1A), with the overall survival (OS) from treatment with nivolumab being 15.5 (95\% CI: 8.3-not reached [NR]) months (Figure 1B).

\section{Efficacy of nivolumab according to clinical parameters}

The details of the ORR of nivolumab based upon the clinical parameters are shown in Table 2. The ORR of patients with elevated CRP levels was significantly worse that those without elevated CRP levels (8.3 vs $25.0 \%, P=0.02$ ). The PFS and OS in patients treated with nivolumab based upon clinical parameters is shown in Table 3. The PS, smoking index (SI), serum CRP values, and LDH values were significant factors for both PFS and OS in patients treated with nivolumab (Figure 2).

\section{Association between efficacy of nivolumab and PD-L1 expression}

In the $89(72 \%)$ patients who had sufficient tumor tissues to evaluate quantifiable PD-L1 expression, 38 (43\%) patients had PD-L1 negative expression, and 51 (57\%) had PD-L1 positive expression, including 9 patients with more than $50 \%$ ( $\geq 50 \%$ ) PD-L1 expression (Table 1). The ORR was significantly higher in patients with PD-L1 positive expression than those with PD-L1 negative expression $(33 \%$ vs. $1.1 \%, P<0.01)$. There was no difference in the ORR in patients with between $1-49 \%$ and $\geq 50 \%$ PD-L1 expression (33\% vs. $33 \%, P>0.99)$. The PFS and OS were significantly longer in patients with PD-L1 positive expression compared to those with PD-L1 negative expression (median PFS: 1.8 (95\% CI: 1.4-2.8) months vs. 5.3 (95\% CI: 2.2-9.3) months (Figure 3A), $P<0.01$, and median OS: 8.4 (95\% CI: 5.0-NR) months vs. NR (8.4-NR) months, $P=0.04$ ) (Figure $3 \mathrm{~B}$ ).

\section{The multivariate analysis for the PFS of Nivolumab treatment}

Multivariate analysis for PFS on nivolumab in 89 patients assessed by PD-L1 expression identified five 
factors associated with a longer PFS using nivolumab [LDH (< 245IU/L), HR: 0.55 (95\% CI: 0.31-0.99), $P=0.04$; CRP (<1.0 mg/dl), HR: 0.48 (95\% CI: $0.27-$ $0.82), P=0.01$; PD-L1 expression positive, HR: 0.56 (95\% CI: 0.33-0.98), $P=0.03$; PS (0-1), HR: 0.42 (95\% CI: $0.19-0.96), P=0.04$; and SI $\geq 400$, HR: 0.53 (95\% CI: 0.31-0.90), $P=0.02$ ] (Table 4).

\section{DISCUSSION}

We found that PS, serum CRP and LDH values, smoking status, and PD-L1 expression were significantly associated with the PFS and survival in patients treated with nivolumab. Some reports have shown that PD-L1 expression and smoking status were predictive factors for the efficacy of nivolumab [2, 3, 8-10, 27, 28]. This is the first report to show that clinical parameters, such as serum CRP and LDH values, and PS are significantly associated with the response duration of nivolumab and survival in advanced NSCLC patients treated with nivolumab.
There have been some reports on the association between the clinical benefits of immune checkpoint inhibitors and clinical parameters, including laboratory data, in metastatic melanoma patients [18-21]. They showed that LDH at the baseline and changes in $\mathrm{LDH}$ correlate with response to another immune checkpoint inhibitor, ipilimumab, in melanoma patients [19, 29]. In addition, Diem et al. reported that serum LDH levels at baseline and during treatment could be a useful marker to predict the responsiveness or the progression in advanced melanoma patients who receive anti-PD-1 therapy [18]. $\mathrm{LDH}$ is the final enzyme in the glycolysis pathway that catalyzes interconversion of pyruvate and lactate. The gene expression and activity of LDH are often upregulated in cancer patients [30, 31]. High serum LDH levels have been linked to poor prognosis, which was consistent with our study [31-34]. In general, activated T cells, which are the key players in the anti-tumor responses of nivolumab, have been reported to use glycolysis as their main energy source [35]. As tumor cells release high amounts of
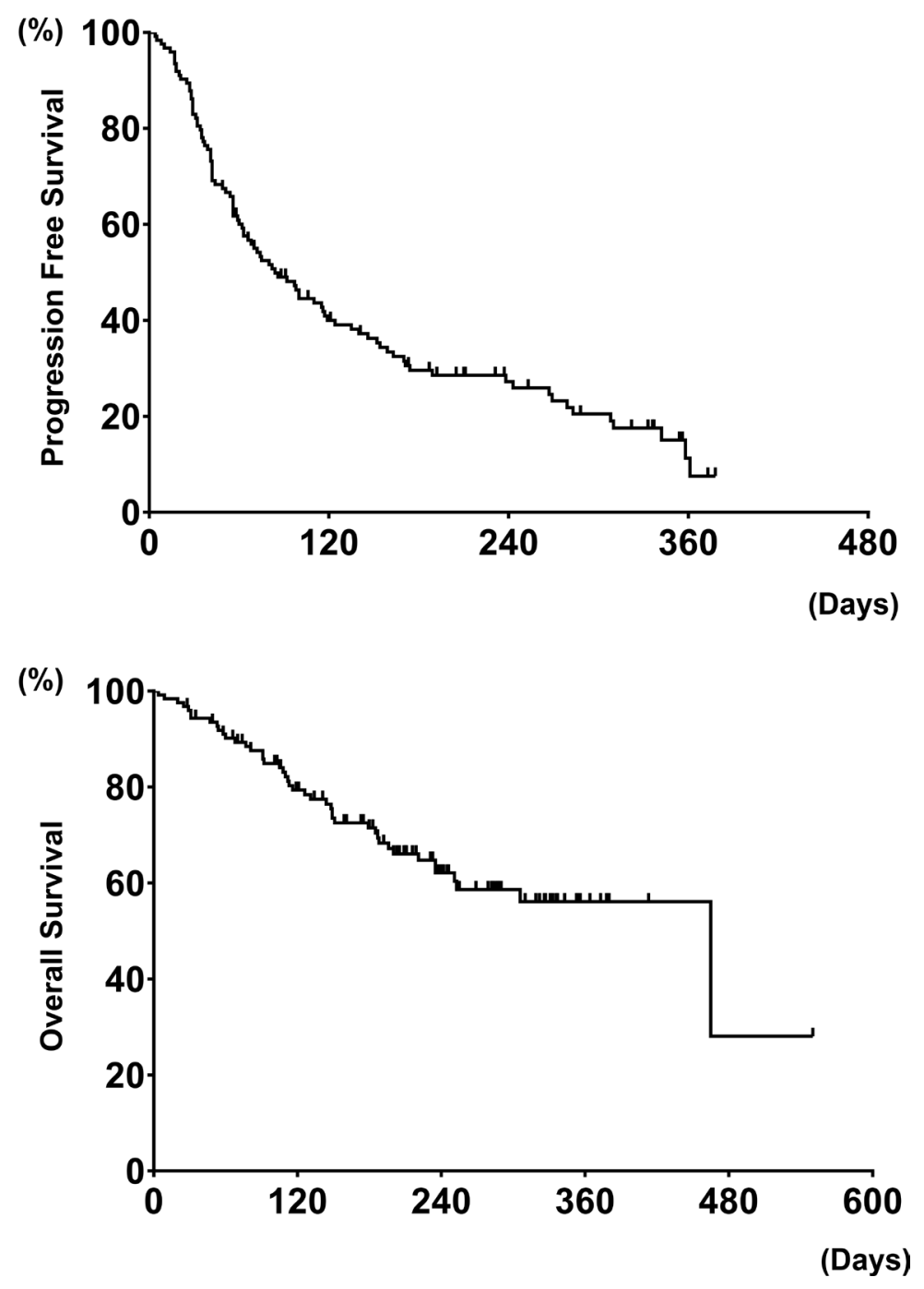

Figure 1: Progression free survival on nivolumab and overall survival from treatment with nivolumab in all patients $(N=124)$ (A and B). 
Table 1: Patient characteristics $(N=124)$

\begin{tabular}{|c|c|c|c|}
\hline Characteristics & & $\mathbf{N}$ & $(\%)$ \\
\hline Age & Median [range] & $66(37-79)$ & \\
\hline Sex & Male/Female & $87 / 37$ & $70 / 30$ \\
\hline PS & $\begin{array}{l}0-1 \\
2 / 3\end{array}$ & $\begin{array}{l}109 \\
12 / 3\end{array}$ & $\begin{array}{c}88 \\
10 / 2\end{array}$ \\
\hline Histology & $\begin{array}{l}\text { Adenocarcinoma } \\
\text { Squamous cell carcinoma } \\
\text { Others }\end{array}$ & $\begin{array}{l}81 \\
27 \\
16\end{array}$ & $\begin{array}{l}65 \\
22 \\
13\end{array}$ \\
\hline Smoking & $\begin{array}{l}\text { Heavy Smoker }(\mathrm{SI} \geq 400) \\
\text { Light smoker }(0<\mathrm{SI}<400) \\
\text { Never smoker }(\mathrm{SI}=0)\end{array}$ & $\begin{array}{l}77 \\
20 \\
27\end{array}$ & $\begin{array}{l}62 \\
16 \\
22\end{array}$ \\
\hline Smoking index & Median [range] & 630 [0-2520] & \\
\hline Mutation & $\begin{array}{l}E G F R \\
K R A S \\
H E R 2 \\
B R A F \\
\text { None or Unknown }\end{array}$ & $\begin{array}{c}22 \\
14 \\
5 \\
2 \\
81\end{array}$ & $\begin{array}{c}18 \\
11 \\
4 \\
2 \\
65\end{array}$ \\
\hline Treatment line & $\begin{array}{l}\text { Second } \\
\text { Third } \\
\geq \text { Fourth }\end{array}$ & $\begin{array}{l}58 \\
20 \\
46\end{array}$ & $\begin{array}{l}47 \\
16 \\
37\end{array}$ \\
\hline PD-L1 expression & $\begin{array}{l}0 \\
1-49 \\
50- \\
\text { Unknown }\end{array}$ & $\begin{array}{c}38 \\
42 \\
9 \\
35\end{array}$ & $\begin{array}{c}31 \\
34 \\
7 \\
28\end{array}$ \\
\hline LDH & $\begin{array}{l}<245 \mathrm{IU} / \mathrm{L} \\
\geq 245 \mathrm{IU} / \mathrm{L}\end{array}$ & $\begin{array}{l}73 \\
51\end{array}$ & $\begin{array}{l}59 \\
41\end{array}$ \\
\hline CRP & $\begin{array}{l}<1.0 \mathrm{mg} / \mathrm{dl} \\
\geq 1.0 \mathrm{mg} / \mathrm{dl}\end{array}$ & $\begin{array}{l}64 \\
60\end{array}$ & $\begin{array}{l}52 \\
48\end{array}$ \\
\hline
\end{tabular}

Abbreviations: PS, performance status; SI; smoking index.

lactate to the extracellular space, T-cells are not able to rid themselves of their own lactate. The extracellular lactate inactivates the cytokine release from dendritic cells and activated T-cells [36, 37]. These findings could mean that serum LDH levels are associated with the efficacy of immunotherapy, such as immune checkpoint inhibitors.

Our study also indicated that serum CRP levels are associated with the response to nivolumab. Serum CRP is one of the major acute-phase proteins, and is considered a definitive marker of systemic inflammation. In clinical practice, CRP is commonly used to evaluate the severity of systemic inflammation or outcomes of a variety of inflammation-related disorders. In the normal population, $70 \%-90 \%$ of samples have a CRP concentration of less than $0.3 \mathrm{mg} / \mathrm{dl}$, while serum CRP levels in cancer patients are significantly higher and linked with tumor burden and disease progression [38]. Additionally, elevated serum CRP levels are associated with increased IL-6 production by tumor cells or by surrounding tissues. IL- 6 has been reported to promote tumor-cell survival, and a higher level of IL-6 was significantly associated with an unfavorable prognosis in cancer patients $[39,40]$. In this study, the reasons for the association with serum CRP levels and the efficacy of nivolumab remain unclear, but serum CRP and IL-6 levels have previously been shown to predict tumor response and survival to immunotherapy, such as high dose IL-2, IFN alpha, and ipilimumab [41-44]. Further investigation into the actions of IL- 6 and CRP on immunotherapy efficacy is needed.

PS is a commonly used factor to determine the treatment and prognosis in patients with NSCLC. Advanced NSCLC patients with a poor PS (generally PS 3) do not benefit from standard chemotherapy [45]. In contrast, EGFR mutation-positive and ALK positive NSCLC patients with extremely poor PS often benefit from EGFR-TKIs and ALK-TKIs, which achieve high activity with acceptable toxicity levels in patients with a poor PS [46-48]. This study showed that the PS was a negative significant predictive factor for the efficacy of nivolumab. In our study, no patients with a PS 2-3 experienced a response to nivolumab, even if they have PD-L1 positive expression. The reasons for the lack 
A

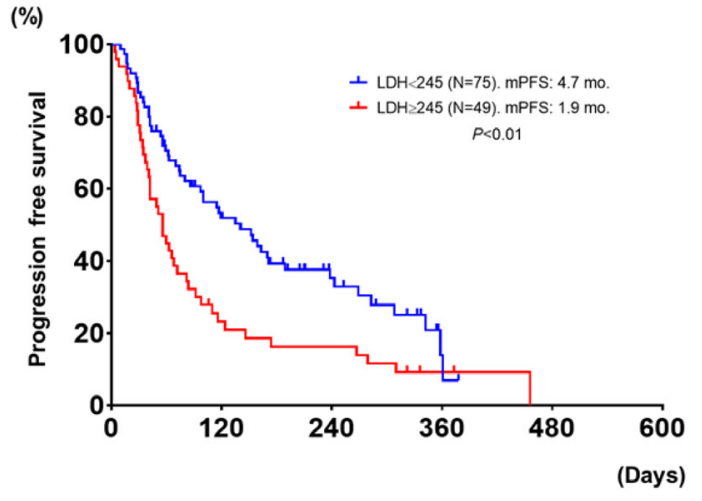

C

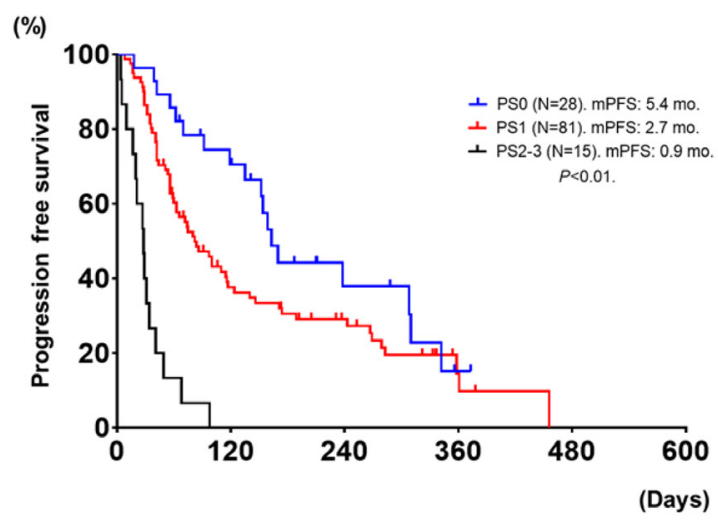

E

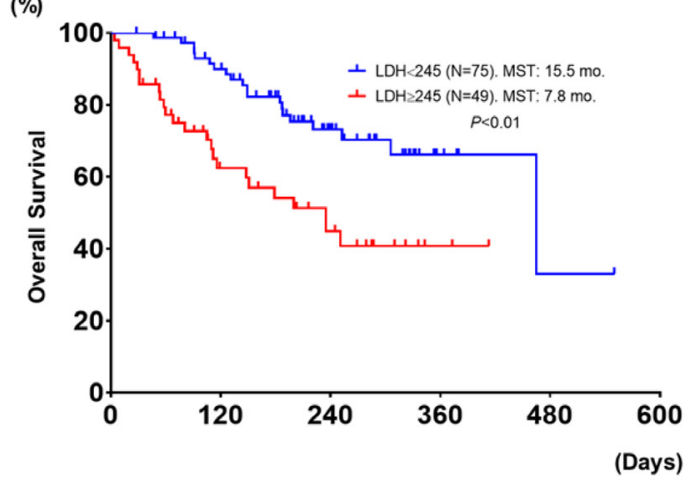

$\mathbf{G}$

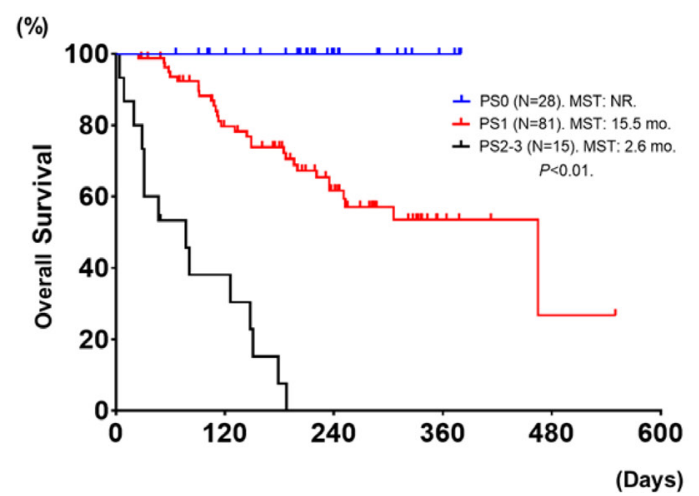

B \%)

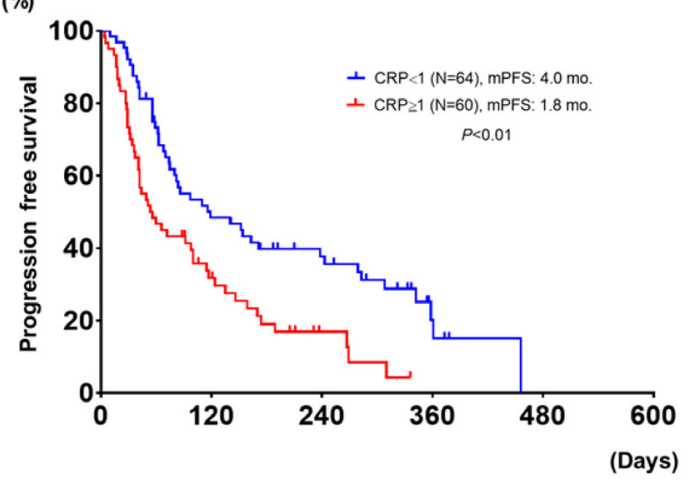

D

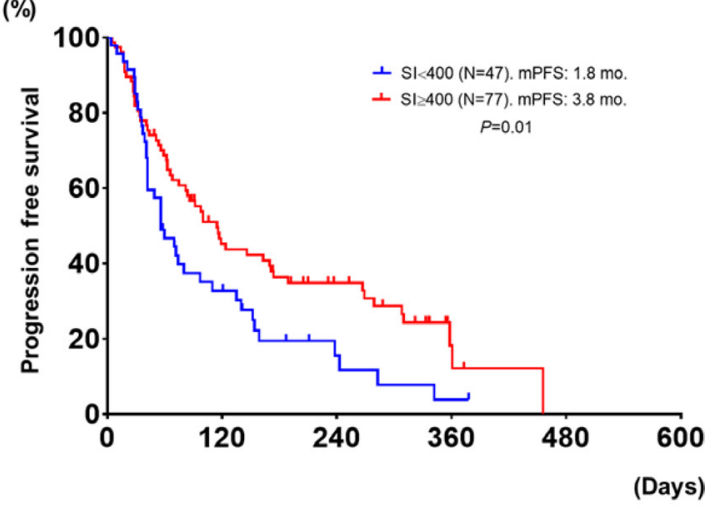

$\boldsymbol{F}^{(\%)}$

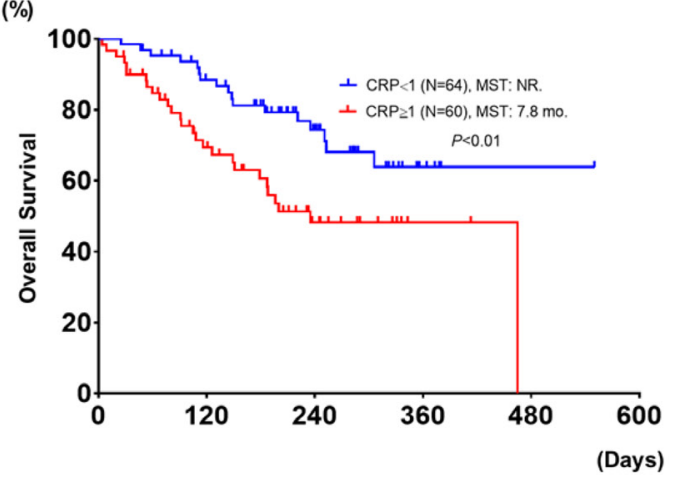

H

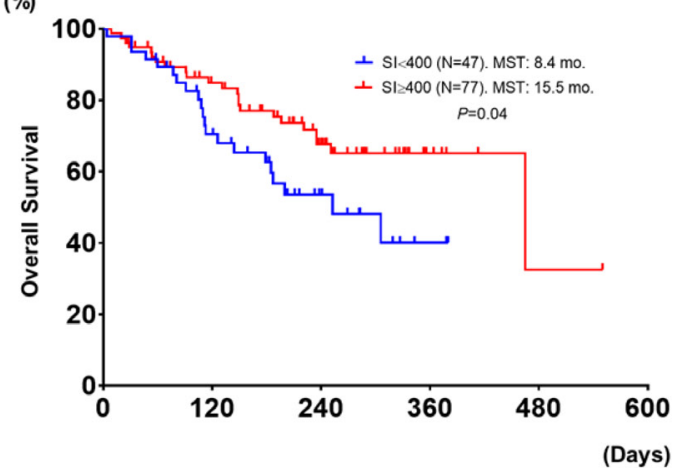

Figure 2: Progression free survival and overall survival in patients treated with nivolumab, based upon different LDH ( $\geq 245$ vs. $<245$ ), (A and $\mathbf{E}), \mathrm{CRP}(\geq 1$ vs. $<1),(\mathbf{B}$ and $\mathbf{F}), \mathrm{PS}(0$ vs. 1 vs. 2$),(\mathbf{C}$ and $\mathbf{G})$, and SI ( $\geq 400$ vs. $<400)$, (D and $\mathbf{H})$. mPFS; median progression free survival, mo; months, NR; not reached, and MST; median survival time. 
Table 2: Details on the efficacy of nivolumab based upon clinical parameters $(N=124)$

\begin{tabular}{|c|c|c|c|c|}
\hline Parameters & & & Response to Nivolumab, N (\%) & $P$-value \\
\hline Age & $\begin{array}{l}\geq 75 \\
<75\end{array}$ & $\begin{array}{l}(N=10) \\
(N=114)\end{array}$ & $\begin{array}{c}1(10.0) \\
20(17.5)\end{array}$ & $>0.99$ \\
\hline Sex & $\begin{array}{l}\text { Male } \\
\text { Female }\end{array}$ & $\begin{array}{l}(N=87) \\
(N=37)\end{array}$ & $\begin{array}{c}16(18.3) \\
5(13.5)\end{array}$ & 0.79 \\
\hline SI & $\begin{array}{l}\geq 400 \\
<400\end{array}$ & $\begin{array}{l}(N=77) \\
(N=47)\end{array}$ & $\begin{array}{c}17(22.1) \\
4(8.5)\end{array}$ & 0.08 \\
\hline PS & $\begin{array}{l}0 \\
1 \\
2-3\end{array}$ & $\begin{array}{l}(N=28) \\
(N=81) \\
(N=15)\end{array}$ & $\begin{array}{c}7(25.0) \\
14(17.3) \\
0(0.0)\end{array}$ & 0.10 \\
\hline Histology & $\begin{array}{l}\text { Ad } \\
\text { Sq } \\
\text { Others }\end{array}$ & $\begin{array}{l}(N=81) \\
(N=27) \\
(N=16)\end{array}$ & $\begin{array}{c}9(9.0) \\
7(26.0) \\
5(31.3)\end{array}$ & 0.05 \\
\hline LDH & $\begin{array}{l}\geq 245 \mathrm{IU} / \mathrm{L} \\
<245 \mathrm{IU} / \mathrm{L}\end{array}$ & $\begin{array}{l}(N=49) \\
(N=75)\end{array}$ & $\begin{array}{c}8(16.3) \\
13(17.3)\end{array}$ & $>0.99$ \\
\hline CRP & $\begin{array}{l}\geq 1.0 \mathrm{mg} / \mathrm{dl} \\
<1.0 \mathrm{mg} / \mathrm{dl}\end{array}$ & $\begin{array}{l}(N=60) \\
(N=64)\end{array}$ & $\begin{array}{c}5(8.3) \\
16(25.0)\end{array}$ & 0.02 \\
\hline Mutation status & $\begin{array}{l}E G F R \\
K R A S \\
\text { Others } \\
H E R 2 \\
B R A F \\
\text { None/Unknown }\end{array}$ & $\begin{array}{l}(N=22) \\
(N=14) \\
(N=7) \\
(N=5) \\
(N=2) \\
(N=81)\end{array}$ & $\begin{array}{c}2(9.0) \\
4(28.5) \\
1(14.2) \\
1(20.0) \\
0(0) \\
14(17.2)\end{array}$ & 0.50 \\
\hline
\end{tabular}

Abbreviations: SI, smoking index; Ad, adenocarcinoma; Sq, Squamous cell carcinoma.

of response in patients with a poor PS remain unclear, but the PS might reflect the immune state of patients and the tumor microenvironment. The immune system can perceive and eliminate some tumors early in their development. Based on the theory of immunoediting which involves the process of immunosurveillance, as tumors spread throughout the body, tumors can escape from the immune system through different mechanisms, such as alterations of reduced immune recognition, increased resistance to the cytotoxic effects of immunity, and the formation of an immunosuppressive state within the tumor microenvironment [49-51]. Therefore, the results of our study may suggest that the immune status of patients with poor a PS could be more immunosuppressive.

There were several limitations in this study. First, this was a retrospective study with a small sample size. Second, it is unclear whether the cutoff value for the LDH and CRP was relevant. Some reports have also shown that melanoma patients with an elevated baseline LDH had significantly shorter survivals compared to patients with a normal LDH treated with immune checkpoint inhibitors $[18,29]$. There have been no reports on the differences in the efficacy of immune checkpoint inhibitors based upon different CRP levels. Thus, we analyzed the overall response rate of nivolumab based upon different CRP levels (Supplemental Table 1). Based on the distribution, a CRP of $1.0 \mathrm{mg} / \mathrm{dl}$ could be reasonable as the cutoff value. Thirdly, this study did not include information on AEs. In melanoma patients, AEs, including vitiligo and rash, were reported to be good prognostic factors for melanoma patients treated with nivolumab $[52,53]$. Given these limitations, prospective trials will be required to confirm the impact of clinical parameters on the efficacy of immune checkpoint inhibitor treatments.

In conclusion, reliable predictive markers that can be used to select patients with a higher likelihood of benefit from immune checkpoint inhibitors remain unclear. Immune checkpoint inhibitors offer a new treatment for survival prolongation in advanced NSCLC patients. We found that PS and the levels of serum CRP and LDH values are not only prognostic factors, but also might be predictive factors for the PFS of treatment with nivolumab. This study might suggest that the efficacy of nivolumab likely depends on both tumor biomarkers and the patient status. Unlike treatment with $E G F R$-TKIs and $A L K$-TKIs, advanced NSCLC patients with high levels of serum CRP, serum LDH, and a poor PS might not be suitable for treatment with nivolumab. Further investigation including the efficacy of nivolumab in patients with a poor PS is warranted. 


\section{MATERIALS AND METHODS}

\section{Patients}

We retrospectively analyzed 124 advanced, previously treated NSCLC patients who received nivolumab as subsequent treatment from January 2015 to January 2017 at the Aichi cancer center hospital. The patient characteristics, genetic characteristics (EGFR, $\mathrm{v}$-Ki-ras2 Kirsten rat sarcoma viral oncogene homolog $[K R A S]$, anaplastic lymphoma kinase [ALK], human epidermal growth factor receptor type 2[HER2], and $B R A F)$, laboratory data at the baseline (CRP and LDH), PD-L1 expression of the tumor, nivolumab response, progression-free survival (PFS) of nivolumab, and overall survival (OS) were followed. Serum LDH and CRP levels were measured just before the initiation of treatment with nivolumab. The cutoff values for LDH and CRP were determined based upon standard values and previous reports $[18,22,23]$. For this study, serum lactate dehydrogenase $(<245$ vs. $\geq 245 \mathrm{IU} / \mathrm{L})$, and serum CRP $(<1.0 \mathrm{vs} . \geq 1.0 \mathrm{mg} / \mathrm{dl})$ were the defined levels.

\section{Nivolumab treatment and response}

Patients received at least one infusion of nivolumab ( $3 \mathrm{mg} / \mathrm{kg}$ every 2 weeks) as monotherapy. Patients continued this therapy until they showed progressive

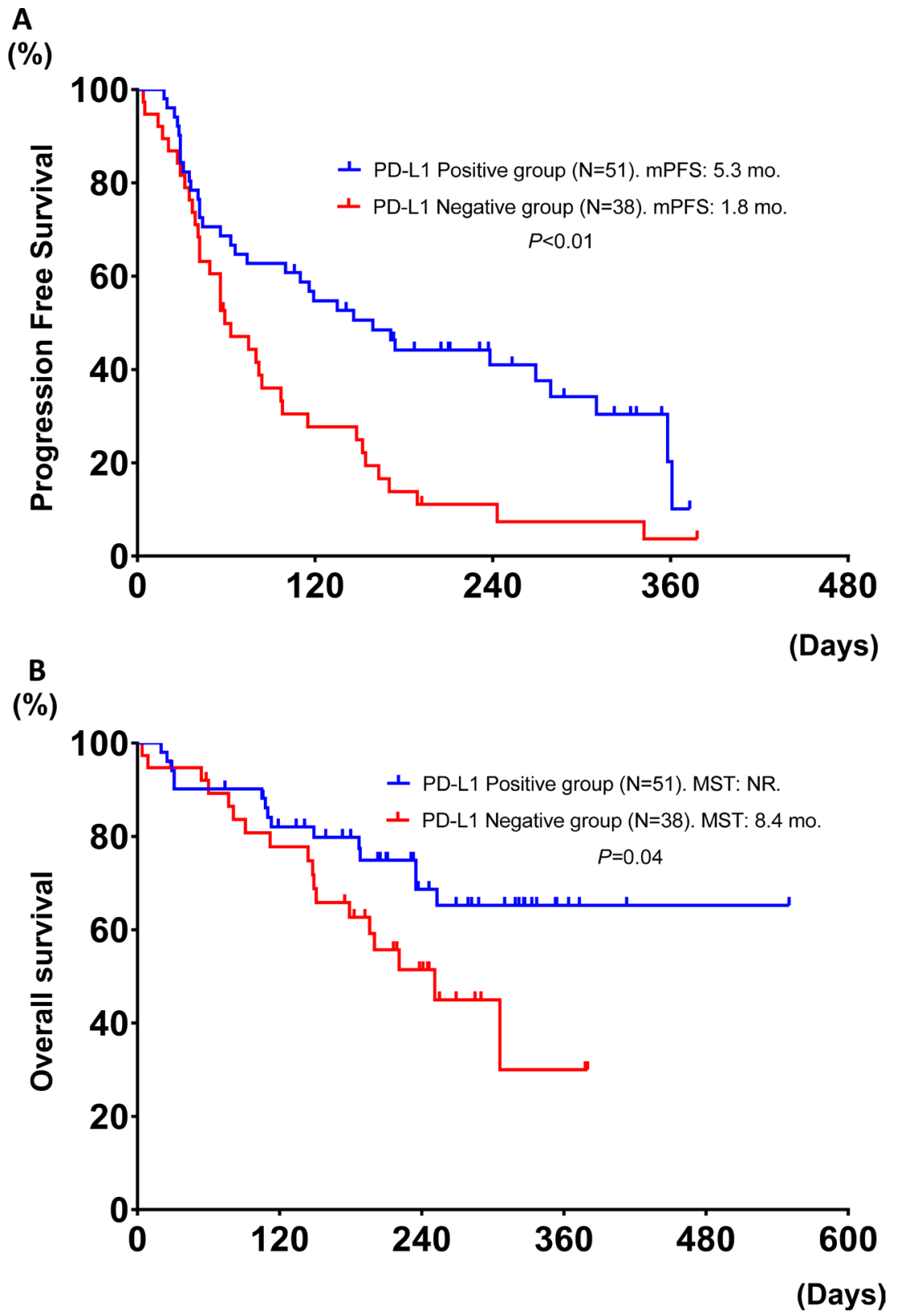

Figure 3: Progression free survival and overall survival in patients treated with nivolumab, based upon PD-L1 expression (positive vs. negative) $(\mathrm{N}=89)(\mathrm{A}$ and $\mathrm{B})$. 
Table 3: PFS and OS in patients treated with nivolumab based upon clinical parameters $(N=124)$

\begin{tabular}{|c|c|c|c|c|c|c|}
\hline \multicolumn{3}{|c|}{ Parameters } & \multirow{2}{*}{$\begin{array}{c}\text { Median PFS } \\
\text { Months (95\% CI) } \\
2.7(1.1-\mathrm{NR}) \\
3.8(2.0-3.9)\end{array}$} & \multirow{2}{*}{$\begin{array}{c}\boldsymbol{P} \text {-Value } \\
0.36\end{array}$} & \multirow{2}{*}{$\begin{array}{l}\text { MST Months } \\
\text { (95\% CI) } \\
\text { NR (7.9-NR) } \\
15.5(3.0-15.5)\end{array}$} & \multirow{2}{*}{$\begin{array}{r}\boldsymbol{P} \text {-Value } \\
0.34\end{array}$} \\
\hline Age & $\begin{array}{l}\geq 75 \\
<75\end{array}$ & $\begin{array}{l}(N=10) \\
(N=114)\end{array}$ & & & & \\
\hline Sex & $\begin{array}{l}\text { Male } \\
\text { Female }\end{array}$ & $\begin{array}{l}(N=87) \\
(N=37)\end{array}$ & $\begin{array}{l}3.3(2.1-4.3) \\
2.3(1.4-4.7)\end{array}$ & 0.59 & $\begin{array}{c}15.5(8.4-15.5) \\
10.2(6.0-N R)\end{array}$ & 0.35 \\
\hline SI & $\begin{array}{l}\geq 400 \\
<400\end{array}$ & $\begin{array}{l}(N=77) \\
(N=47)\end{array}$ & $\begin{array}{l}3.8(2.5-5.7) \\
1.8(1.4-3.2)\end{array}$ & 0.01 & $\begin{array}{c}15.5 \text { (15.5-NR) } \\
8.4(4.8-\mathrm{NR})\end{array}$ & 0.04 \\
\hline PS & $\begin{array}{l}0 \\
1 \\
2-3\end{array}$ & $\begin{array}{l}(N=28) \\
(N=81) \\
(N=15)\end{array}$ & $\begin{array}{l}5.4(4.0-10.3) \\
2.7(2.0-3.9) \\
0.9(0.3-1.1)\end{array}$ & $<0.01$ & $\begin{array}{c}\text { NR (NR-NR) } \\
15.5(7.8-N R) \\
2.6(0.7-5.0)\end{array}$ & $<0.01$ \\
\hline Histology & $\begin{array}{l}\text { Ad } \\
\text { Sq } \\
\text { Others }\end{array}$ & $\begin{array}{l}(N=81) \\
(N=27) \\
(N=16)\end{array}$ & $\begin{array}{l}2.4(1.9-3.3) \\
4.9(1.5-9.3) \\
3.2(1.4-\mathrm{NR})\end{array}$ & 0.38 & $\begin{array}{c}\text { NR (8.4-NR) } \\
15.5 \text { (NR-NR) } \\
7.8(3.9-N R)\end{array}$ & 0.19 \\
\hline LDH & $\begin{array}{l}\geq 245 \mathrm{IU} / \mathrm{L} \\
<245 \mathrm{IU} / \mathrm{L}\end{array}$ & $\begin{array}{l}(N=49) \\
(N=75)\end{array}$ & $\begin{array}{l}1.9(1.3-2.7) \\
4.7(2.6-6.3)\end{array}$ & $<0.01$ & $\begin{array}{c}7.8 \text { (3.9-NR) } \\
15.5 \text { (10.2-NR) }\end{array}$ & $<0.01$ \\
\hline CRP & $\begin{array}{l}\geq 1.0 \mathrm{mg} / \mathrm{dl} \\
<1.0 \mathrm{mg} / \mathrm{dl}\end{array}$ & $\begin{array}{l}(N=60) \\
(N=64)\end{array}$ & $\begin{array}{l}1.8(1.4-3.3) \\
4.0(1.9-7.9)\end{array}$ & $<0.01$ & $\begin{array}{r}7.8(5.0-15.5) \\
\text { NR (10.2-NR) }\end{array}$ & $<0.01$ \\
\hline $\begin{array}{l}\text { Mutation } \\
\text { status }\end{array}$ & $\begin{array}{l}\text { EGFR } \\
\text { KRAS } \\
\text { Others } \\
\text { HER2 } \\
\text { BRAF } \\
\text { None/Unknown }\end{array}$ & $\begin{array}{l}(N=22) \\
(N=14) \\
(N=7) \\
(N=5) \\
(N=2) \\
(N=81)\end{array}$ & $\begin{array}{l}1.9(1.2-5.1) \\
1.9(0.9-3.9) \\
3.8(1.2-4.7)\end{array}$ & 0.17 & $\begin{array}{c}8.4(4.2-\mathrm{NR}) \\
6.6(3.0-\mathrm{NR}) \\
\mathrm{NR}(10.2-\mathrm{NR})\end{array}$ & 0.42 \\
\hline
\end{tabular}

Abbreviations: MST; median survival time, NR; not reached.

Table 4: The multivariate analysis of predictive factors for efficacy of Nivolumab $(N=89)$

\begin{tabular}{lcc}
\hline Variables & $\begin{array}{c}\text { Multivariate analysis } \\
\text { HR }(\mathbf{9 5 \%} \mathbf{C I}) \boldsymbol{P} \text {-value }\end{array}$ \\
\hline LDH & 0.55 & 0.04 \\
$<245 \mathrm{IU} / \mathrm{L}(\mathrm{vs} . \geq 245 \mathrm{IU} / \mathrm{L})$ & $(0.31-0.99)$ & 0.01 \\
$\mathrm{CRP}$ & 0.48 & \\
$<1.0 \mathrm{mg} / \mathrm{dl}(\mathrm{vs} . \geq 1.0 \mathrm{mg} / \mathrm{dl})$ & $(0.27-0.82)$ & 0.03 \\
PD-L1 expression & 0.56 & \\
Positive (vs. negative) & $0.33-0.98$ & 0.04 \\
PS & 0.42 & \\
$0-1$ (vs. $2-3)$ & $(0.19-0.96)$ & 0.02 \\
SI & 0.53 & \\
$\geq 400$ (vs. $<400)$ & $(0.31-0.90)$ & \\
\hline
\end{tabular}

Abbreviations: LDH: lactate dehydrogenase, CRP: C-reactive protein, SI: Smoking index, HR: hazard ratio.

disease or experienced unacceptable adverse events. In general, patients underwent radiographic imaging every 2 months, and were evaluated for tumor response according to the response evaluation criteria in solid tumors, version 1.1 [24]. The ORR was calculated as the total percentage of patients with a complete response or a partial response.
Mutation Analyses of EGFR, ALK, KRAS, HER2, and $B R A F$

EGFR mutations (exons 18-21) were identified using the cycleave polymerase chain reaction method. HER2 (exon 20), KRAS (exons 2-3) and BRAF mutations (exons 11-15) were analyzed using fragment analysis, 
and the results were partially validated with direct sequencing, as previously reported [25]. ALK fusions were examined by reverse transcriptase PCR (RTPCR), immunohistochemistry or fluorescence in situ hybridization assays (Vysis ALK Break Apart FISH Probe Kit; Vysis, Inc, Downers Grove, IL, USA), and a tumor was considered to be ALK positive when at least 2 of the RT-PCR, IHC, or FISH tests had positive results, as previously reported [26].

\section{PD-L1 expression analysis}

Tumor PD-L1 protein expression was evaluated retrospectively in pretreatment (archival or recent) tumorbiopsy or surgical resection specimens with the use of an automated immunohistochemistry (IHC) assay (Dako, North America) that used rabbit monoclonal antihuman PD-L1 antibody (clone 28-8, Epitomics). Tumors were defined as PD-L1 positive when staining of the tumor-cell membrane (at any intensity) was observed at pre-specified expression levels of $1 \%$ or higher in a section that included at least 100 tumor cells for evaluation. In 124 patients, we identified 89 (72\%) patients with tumor specimens that were evaluated for PD-L1 expression.

\section{Statistical analysis}

All the statistical analyses were performed using the JMP version 11 statistical software package (SAS Institute, Cary, NC, USA). Differences in the baseline characteristics between the groups were compared using Fisher's exact tests for categorical data. The PFS was calculated from the date of therapy initiation to disease progression. The OS was calculated from the date of nivolumab therapy initiation to death and censored at the date of last visit for patients whose death could not be confirmed. The survival probabilities were estimated using the Kaplan-Meier method, where differences in the variables were calculated using the log-rank test. Multivariate regression analysis was conducted according to the Cox proportional hazard model. Covariates with $P \leq 0.05$ in the univariate analysis were included in the multivariate model. The database was locked on January 31th, 2017. At the time of the database lock, 44 of the 124 patients had died. This study was approved by the Institutional Review Board of the Aichi Cancer Center.

\section{CONFLICTS OF INTEREST}

None.

\section{FINANCIAL SUPPORT}

This research did not receive any specific grant from funding agencies in the public, commercial, or not-forprofit sectors.

\section{REFERENCES}

1. Wang C, Thudium KB, Han M, Wang XT, Huang H, Feingersh D, Garcia C, Wu Y, Kuhne M, Srinivasan M, Singh S, Wong S, Garner N, et al. In vitro characterization of the anti-PD-1 antibody nivolumab, BMS-936558, and in vivo toxicology in non-human primates. Cancer Immunol Res. 2014; 2:846-56. https://doi.org/10.1158/2326-6066. CIR-14-0040.

2. Borghaei H, Paz-Ares L, Horn L, Spigel DR, Steins M, Ready NE, Chow LQ, Vokes EE, Felip E, Holgado E, Barlesi F, Kohlhaufl M, Arrieta O, et al. Nivolumab versus Docetaxel in Advanced Nonsquamous Non-Small-Cell Lung Cancer. N Engl J Med. 2015; 373:1627-39. https:// doi.org/10.1056/NEJMoa1507643.

3. Brahmer J, Reckamp KL, Baas P, Crino L, Eberhardt WE, Poddubskaya E, Antonia S, Pluzanski A, Vokes EE, Holgado E, Waterhouse D, Ready N, Gainor J, et al. Nivolumab versus Docetaxel in Advanced SquamousCell Non-Small-Cell Lung Cancer. N Engl J Med. 2015; 373:123-35. https://doi.org/10.1056/NEJMoa1504627.

4. Fossella FV, DeVore R, Kerr RN, Crawford J, Natale RR, Dunphy F, Kalman L, Miller V, Lee JS, Moore M, Gandara D, Karp D, Vokes E, et al. Randomized phase III trial of docetaxel versus vinorelbine or ifosfamide in patients with advanced non-small-cell lung cancer previously treated with platinum-containing chemotherapy regimens. The TAX 320 Non-Small Cell Lung Cancer Study Group. J Clin Oncol. 2000; 18:2354-62. https://doi.org/10.1200/ JCO.2000.18.12.2354.

5. Shepherd FA, Dancey J, Ramlau R, Mattson K, Gralla R, O'Rourke M, Levitan N, Gressot L, Vincent M, Burkes R, Coughlin S, Kim Y, Berille J. Prospective randomized trial of docetaxel versus best supportive care in patients with non-small-cell lung cancer previously treated with platinumbased chemotherapy. J Clin Oncol. 2000; 18:2095-103. https://doi.org/10.1200/JCO.2000.18.10.2095.

6. McDermott DF, Drake CG, Sznol M, Choueiri TK, Powderly JD, Smith DC, Brahmer JR, Carvajal RD, Hammers HJ, Puzanov I, Hodi FS, Kluger HM, Topalian SL, et al. Survival, Durable Response, and Long-Term Safety in Patients With Previously Treated Advanced Renal Cell Carcinoma Receiving Nivolumab. J Clin Oncol. 2015; 33:2013-20. https://doi.org/10.1200/JCO.2014.58.1041.

7. Topalian SL, Sznol M, McDermott DF, Kluger HM, Carvajal RD, Sharfman WH, Brahmer JR, Lawrence DP, Atkins MB, Powderly JD, Leming PD, Lipson EJ, Puzanov I, et al. Survival, durable tumor remission, and long-term safety in patients with advanced melanoma receiving nivolumab. J Clin Oncol. 2014; 32:1020-30. https://doi. org/10.1200/JCO.2013.53.0105.

8. Topalian SL, Hodi FS, Brahmer JR, Gettinger SN, Smith DC, McDermott DF, Powderly JD, Carvajal RD, Sosman JA, Atkins MB, Leming PD, Spigel DR, Antonia SJ, et al. Safety, activity, and immune correlates of anti-PD-1 
antibody in cancer. N Engl J Med. 2012; 366:2443-54. https://doi.org/10.1056/NEJMoa1200690.

9. Taube JM, Klein A, Brahmer JR, Xu H, Pan X, Kim JH, Chen L, Pardoll DM, Topalian SL, Anders RA. Association of PD-1, PD-1 ligands, and other features of the tumor immune microenvironment with response to anti-PD-1 therapy. Clin Cancer Res. 2014; 20:5064-74. https://doi. org/10.1158/1078-0432.CCR-13-3271.

10. Reck M, Rodríguez-Abreu D, Robinson AG, Hui R, Csőszi T, Fülöp A, Gottfried M, Peled N, Tafreshi A, Cuffe S, O'Brien M, Rao S, Hotta K, et al, and KEYNOTE-024 Investigators. Pembrolizumab versus Chemotherapy for PD-L1-Positive Non-Small-Cell Lung Cancer. N Engl J Med. 2016; 375:1823-33. https://doi.org/10.1056/ NEJMoa1606774.

11. Rizvi NA, Hellmann MD, Snyder A, Kvistborg P, Makarov V, Havel JJ, Lee W, Yuan J, Wong P, Ho TS, Miller ML, Rekhtman N, Moreira AL, et al. Cancer immunology. Mutational landscape determines sensitivity to PD-1 blockade in non-small cell lung cancer. Science. 2015; 348:124-8. https://doi.org/10.1126/science.aaa1348.

12. Carbone DP, Reck M, Paz-Ares L, Creelan B, Horn L, Steins M, Felip E, van den Heuvel MM, Ciuleanu TE, Badin F, Ready N, Hiltermann TJ, Nair S, et al, and CheckMate 026 Investigators. First-Line Nivolumab in Stage IV or Recurrent Non-Small-Cell Lung Cancer. N Engl J Med. 2017; 376:2415-26. https://doi.org/10.1056/ NEJMoa1613493.

13. Gros A, Parkhurst MR, Tran E, Pasetto A, Robbins PF, Ilyas S, Prickett TD, Gartner JJ, Crystal JS, Roberts IM, TrebskaMcGowan K, Wunderlich JR, Yang JC, et al. Prospective identification of neoantigen-specific lymphocytes in the peripheral blood of melanoma patients. Nat Med. 2016; 22:433-8. https://doi.org/10.1038/nm.4051.

14. Erdag G, Schaefer JT, Smolkin ME, Deacon DH, Shea SM, Dengel LT, Patterson JW, Slingluff CL Jr. Immunotype and immunohistologic characteristics of tumor-infiltrating immune cells are associated with clinical outcome in metastatic melanoma. Cancer Res. 2012; 72:1070-80. https://doi.org/10.1158/0008-5472.CAN-11-3218.

15. Herbst RS, Soria JC, Kowanetz M, Fine GD, Hamid O, Gordon MS, Sosman JA, McDermott DF, Powderly JD, Gettinger SN, Kohrt HE, Horn L, Lawrence DP, et al. Predictive correlates of response to the anti-PD-L1 antibody MPDL3280A in cancer patients. Nature. 2014; 515:563-7. https://doi.org/10.1038/nature14011.

16. Ahmadzadeh M, Johnson LA, Heemskerk B, Wunderlich JR, Dudley ME, White DE, Rosenberg SA. Tumor antigen-specific CD8 T cells infiltrating the tumor express high levels of PD-1 and are functionally impaired. Blood. 2009; 114:1537-44. https://doi.org/10.1182/ blood-2008-12-195792.

17. Lee CK, Man J, Lord S, Links M, Gebski V, Mok T, Yang JC. Checkpoint Inhibitors in Metastatic EGFRMutated Non-Small Cell Lung Cancer-A Meta-Analysis.
J Thorac Oncol. 2017; 12:403-7. https://doi.org/10.1016/j. jtho.2016.10.007.

18. Diem S, Kasenda B, Spain L, Martin-Liberal J, Marconcini $\mathrm{R}$, Gore M, Larkin J. Serum lactate dehydrogenase as an early marker for outcome in patients treated with antiPD-1 therapy in metastatic melanoma. Br J Cancer. 2016; 114:256-61. https://doi.org/10.1038/bjc.2015.467.

19. Dick J, Lang N, Slynko A, Kopp-Schneider A, Schulz C, Dimitrakopoulou-Strauss A, Enk AH, Hassel JC. Use of $\mathrm{LDH}$ and autoimmune side effects to predict response to ipilimumab treatment. Immunotherapy. 2016; 8:1033-44. https://doi.org/10.2217/imt-2016-0083.

20. Heppt MV, Heinzerling L, Kahler KC, Forschner A, Kirchberger MC, Loquai C, Meissner M, Meier F, Terheyden P, Schell B, Herbst R, Goppner D, Kiecker F, et al. Prognostic factors and outcomes in metastatic uveal melanoma treated with programmed cell death-1 or combined PD-1/cytotoxic T-lymphocyte antigen-4 inhibition. Eur J Cancer. 2017; 82:56-65. https://doi. org/10.1016/j.ejca.2017.05.038.

21. Nakamura Y, Kitano S, Takahashi A, Tsutsumida A, Namikawa K, Tanese K, Abe T, Funakoshi T, Yamamoto N, Amagai M, Yamazaki N. Nivolumab for advanced melanoma: pretreatment prognostic factors and early outcome markers during therapy. Oncotarget. 2016; 7:77404-15. https://doi.org/10.18632/oncotarget.12677.

22. Lundin E, Dossus L, Clendenen T, Krogh V, Grankvist K, Wulff M, Sieri S, Arslan AA, Lenner P, Berrino F, Hallmans G, Zeleniuch-Jacquotte A, Toniolo P, et al. C-reactive protein and ovarian cancer: a prospective study nested in three cohorts (Sweden, USA, Italy). Cancer Causes Control. 2009; 20:1151-9. https://doi.org/10.1007/s10552-009-93302.

23. Wu X, Wen CP, Ye Y, Tsai M, Wen C, Roth JA, Pu X, Chow WH, Huff C, Cunningham S, Huang M, Wu S, Tsao CK, et al. Personalized Risk Assessment in Never, Light, and Heavy Smokers in a prospective cohort in Taiwan. Sci Rep. 2016; 6:36482. https://doi.org/10.1038/srep36482.

24. Eisenhauer EA, Therasse P, Bogaerts J, Schwartz LH, Sargent D, Ford R, Dancey J, Arbuck S, Gwyther S, Mooney M, Rubinstein L, Shankar L, Dodd L, et al. New response evaluation criteria in solid tumours: revised RECIST guideline (version 1.1). Eur J Cancer. 2009; 45:228-47. https://doi.org/10.1016/j.ejca.2008.10.026.

25. Tanaka K, Hida T, Oya Y, Yoshida T, Shimizu J, Mizuno T, Kuroda H, Sakakura N, Yoshimura K, Horio Y, Sakao Y, Yatabe Y. Unique prevalence of oncogenic genetic alterations in young patients with lung adenocarcinoma. Cancer. 2017; 123:1731-40. https://doi.org/10.1002/ cncr.30539.

26. Yoshida T, Oya Y, Tanaka K, Shimizu J, Horio Y, Kuroda H, Sakao Y, Hida T, Yatabe Y. Differential Crizotinib Response Duration Among ALK Fusion Variants in ALKPositive Non-Small-Cell Lung Cancer. J Clin Oncol. 2016; 34:3383-9. https://doi.org/10.1200/JCO.2015.65.8732. 
27. Garon EB, Rizvi NA, Hui R, Leighl N, Balmanoukian AS, Eder JP, Patnaik A, Aggarwal C, Gubens M, Horn L, Carcereny E, Ahn MJ, Felip E, et al, and KEYNOTE-001 Investigators. Pembrolizumab for the treatment of nonsmall-cell lung cancer. N Engl J Med. 2015; 372:2018-28. https://doi.org/10.1056/NEJMoa1501824.

28. Gettinger SN, Horn L, Gandhi L, Spigel DR, Antonia SJ, Rizvi NA, Powderly JD, Heist RS, Carvajal RD, Jackman DM, Sequist LV, Smith DC, Leming P, et al. Overall Survival and Long-Term Safety of Nivolumab (AntiProgrammed Death 1 Antibody, BMS-936558, ONO-4538) in Patients With Previously Treated Advanced Non-SmallCell Lung Cancer. J Clin Oncol. 2015; 33:2004-12. https:// doi.org/10.1200/JCO.2014.58.3708.

29. Kelderman S, Heemskerk B, van Tinteren $H$, van den Brom RR, Hospers GA, van den Eertwegh AJ, Kapiteijn EW, de Groot JW, Soetekouw P, Jansen RL, Fiets E, Furness AJ, Renn A, et al. Lactate dehydrogenase as a selection criterion for ipilimumab treatment in metastatic melanoma. Cancer Immunol Immunother. 2014; 63:449-58. https://doi. org/10.1007/s00262-014-1528-9.

30. Fantin VR, St-Pierre J, Leder P. Attenuation of LDH-A expression uncovers a link between glycolysis, mitochondrial physiology, and tumor maintenance. Cancer Cell. 2006; 9:425-34. https://doi.org/10.1016/j.ccr.2006.04.023.

31. Koukourakis MI, Giatromanolaki A, Sivridis E, Bougioukas G, Didilis V, Gatter KC, Harris AL, and Tumour and Angiogenesis Research Group. Lactate dehydrogenase-5 (LDH-5) overexpression in non-small-cell lung cancer tissues is linked to tumour hypoxia, angiogenic factor production and poor prognosis. Br J Cancer. 2003; 89:87785. https://doi.org/10.1038/sj.bjc.6601205.

32. Koukourakis MI, Giatromanolaki A, Sivridis E, Gatter KC, Harris AL, and Tumour Angiogenesis Research Group. Lactate dehydrogenase 5 expression in operable colorectal cancer: strong association with survival and activated vascular endothelial growth factor pathway--a report of the Tumour Angiogenesis Research Group. J Clin Oncol. 2006; 24:4301-8. https://doi.org/10.1200/JCO.2006.05.9501.

33. Ryberg M, Nielsen D, Osterlind K, Andersen PK, Skovsgaard T, Dombernowsky P. Predictors of central nervous system metastasis in patients with metastatic breast cancer. A competing risk analysis of 579 patients treated with epirubicinbased chemotherapy. Breast Cancer Res Treat. 2005; 91:21725. https://doi.org/10.1007/s10549-005-0323-x.

34. Koukourakis MI, Giatromanolaki A, Sivridis E, Gatter KC, Trarbach T, Folprecht G, Shi MM, Lebwohl D, Jalava T, Laurent D, Meinhardt G, Harris AL. Prognostic and predictive role of lactate dehydrogenase 5 expression in colorectal cancer patients treated with PTK787/ZK 222584 (vatalanib) antiangiogenic therapy. Clin Cancer Res. 2011; 17:4892-900. https://doi.org/10.1158/1078-0432.CCR-10-2918.

35. Hirschhaeuser F, Sattler UG, Mueller-Klieser W. Lactate: a metabolic key player in cancer. Cancer Res. 2011; 71:69215. https://doi.org/10.1158/0008-5472.CAN-11-1457.
36. Gottfried E, Kunz-Schughart LA, Ebner S, Mueller-Klieser W, Hoves S, Andreesen R, Mackensen A, Kreutz M. Tumorderived lactic acid modulates dendritic cell activation and antigen expression. Blood. 2006; 107:2013-21. https://doi. org/10.1182/blood-2005-05-1795.

37. Fischer K, Hoffmann P, Voelkl S, Meidenbauer N, Ammer J, Edinger M, Gottfried E, Schwarz S, Rothe G, Hoves S, Renner K, Timischl B, Mackensen A, et al. Inhibitory effect of tumor cell-derived lactic acid on human $\mathrm{T}$ cells. Blood. 2007; 109:3812-9. https://doi.org/10.1182/ blood-2006-07-035972.

38. Koukourakis MI, Kambouromiti G, Pitsiava D, Tsousou P, Tsiarkatsi M, Kartalis G. Serum C-reactive protein (CRP) levels in cancer patients are linked with tumor burden and are reduced by anti-hypertensive medication. Inflammation. 2009; 32:169-75. https://doi.org/10.1007/s10753-009-9116-4.

39. Lo CW, Chen MW, Hsiao M, Wang S, Chen CA, Hsiao SM, Chang JS, Lai TC, Rose-John S, Kuo ML, Wei LH. IL-6 trans-signaling in formation and progression of malignant ascites in ovarian cancer. Cancer Res. 2011; 71:424-34. https://doi.org/10.1158/0008-5472.CAN-10-1496.

40. Wehbe H, Henson R, Meng F, Mize-Berge J, Patel T. Interleukin-6 contributes to growth in cholangiocarcinoma cells by aberrant promoter methylation and gene expression. Cancer Res. 2006; 66:10517-24. https://doi. org/10.1158/0008-5472.CAN-06-2130.

41. Bromwich E, McMillan DC, Lamb GW, Vasey PA, Aitchison M. The systemic inflammatory response, performance status and survival in patients undergoing alpha-interferon treatment for advanced renal cancer. Br J Cancer. 2004; 91:1236-8. https://doi.org/10.1038/ sj.bjc. 6602152 .

42. Tartour E, Blay JY, Dorval T, Escudier B, Mosseri V, Douillard JY, Deneux L, Gorin I, Negrier S, Mathiot C, Pouillart P, Fridman WH. Predictors of clinical response to interleukin-2--based immunotherapy in melanoma patients: a French multiinstitutional study. J Clin Oncol. 1996; 14:1697-703. https://doi.org/10.1200/ JCO.1996.14.5.1697.

43. Ramsey S. The role of the systemic inflammatory response as a biomarker in immunotherapy for renal cell cancer. Mol Diagn Ther. 2009; 13:277-81. https://doi. org/10.2165/11315860-000000000-00000.

44. Damuzzo V, Solito S, Pinton L, Carrozzo E, Valpione S, Pigozzo J, Arboretti Giancristofaro R, Chiarion-Sileni V, Mandruzzato S. Clinical implication of tumor-associated and immunological parameters in melanoma patients treated with ipilimumab. OncoImmunology. 2016; 5:e1249559. https://doi.org/10.1080/2162402X.2016.1249559.

45. Ettinger DS, Wood DE, Aisner DL, Akerley W, Bauman J, Chirieac LR, D'Amico TA, DeCamp MM, Dilling TJ, Dobelbower M, Doebele RC, Govindan R, Gubens MA, et al. Non-Small Cell Lung Cancer, Version 5.2017, NCCN Clinical Practice Guidelines in Oncology. J Natl Compr Canc Netw. 2017; 15:504-35. 
46. Inoue A, Kobayashi K, Usui K, Maemondo M, Okinaga S, Mikami I, Ando M, Yamazaki K, Saijo Y, Gemma A, Miyazawa H, Tanaka T, Ikebuchi K, et al, and North East Japan Gefitinib Study Group. First-line gefitinib for patients with advanced non-small-cell lung cancer harboring epidermal growth factor receptor mutations without indication for chemotherapy. J Clin Oncol. 2009; 27:1394-400. https://doi.org/10.1200/JCO.2008.18.7658.

47. Yoshida T, Hida T, Yatabe Y. Rapid and dramatic response to alectinib in an anaplastic lymphoma kinase rearranged non-small-cell lung cancer patient who is critically ill. Anticancer Drugs. 2016; 27:573-5. https://doi.org/10.1097/ CAD.0000000000000356.

48. Iwama E, Goto $\mathrm{Y}$, Murakami H, Harada T, Tsumura S, Sakashita H, Mori Y, Nakagaki N, Fujita Y, Seike M, Bessho A, Ono M, Okazaki A, et al. Alectinib for Patients with ALK Rearrangement-Positive Non-Small Cell Lung Cancer and a Poor Performance Status (Lung Oncology Group in Kyushu 1401). J Thorac Oncol. 2017; 12:1161-6. https://doi.org/10.1016/j.jtho.2017.02.012.

49. Dunn GP, Old LJ, Schreiber RD. The immunobiology of cancer immunosurveillance and immunoediting. Immunity. 2004; 21:137-48. https://doi.org/10.1016/j. immuni.2004.07.017.
50. Raval RR, Sharabi AB, Walker AJ, Drake CG, Sharma P. Tumor immunology and cancer immunotherapy: summary of the 2013 SITC primer. J Immunother Cancer. 2014; 2:14. https://doi.org/10.1186/2051-1426-2-14.

51. Schreiber RD, Old LJ, Smyth MJ. Cancer immunoediting: integrating immunity's roles in cancer suppression and promotion. Science. 2011; 331:1565-70. https://doi. org/10.1126/science.1203486.

52. Freeman-Keller M, Kim Y, Cronin H, Richards A, Gibney G, Weber JS. Nivolumab in Resected and Unresectable Metastatic Melanoma: Characteristics of Immune-Related Adverse Events and Association with Outcomes. Clin Cancer Res. 2016; 22:886-94. https://doi.org/10.1158/10780432.CCR-15-1136.

53. Weber JS, Dummer R, de Pril V, Lebbé C, Hodi FS, Investigators MD, and MDX010-20 Investigators. Patterns of onset and resolution of immune-related adverse events of special interest with ipilimumab: detailed safety analysis from a phase 3 trial in patients with advanced melanoma. Cancer. 2013; 119:1675-82. https://doi.org/10.1002/ cncr.27969. 